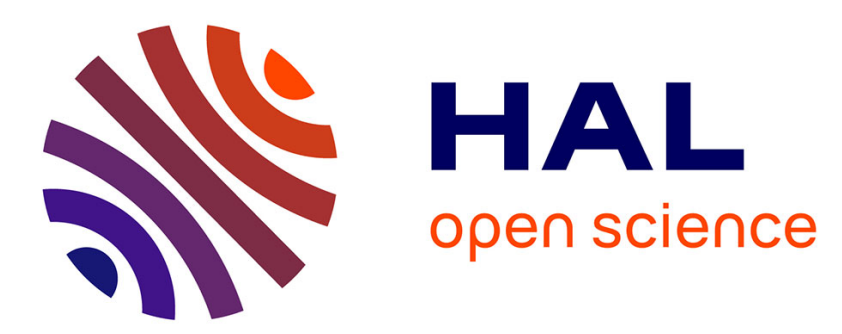

\title{
Full scale experimentation on a new translucent passive solar wall combining silica aerogels and phase change materials
}

Yannick Berthou, Pascal Henry Biwole, Patrick Achard, Hébert Sallée, Mireille Tantot-Neirac, Frédéric Jay

\section{To cite this version:}

Yannick Berthou, Pascal Henry Biwole, Patrick Achard, Hébert Sallée, Mireille Tantot-Neirac, et al.. Full scale experimentation on a new translucent passive solar wall combining silica aerogels and phase change materials. Solar Energy, 2015, 115, pp.733-742. 10.1016/j.solener.2015.03.038 . hal-01140656

\section{HAL Id: hal-01140656 \\ https: / hal-mines-paristech.archives-ouvertes.fr/hal-01140656}

Submitted on 10 Apr 2015

HAL is a multi-disciplinary open access archive for the deposit and dissemination of scientific research documents, whether they are published or not. The documents may come from teaching and research institutions in France or abroad, or from public or private research centers.
L'archive ouverte pluridisciplinaire HAL, est destinée au dépôt et à la diffusion de documents scientifiques de niveau recherche, publiés ou non, émanant des établissements d'enseignement et de recherche français ou étrangers, des laboratoires publics ou privés. 


\title{
Full scale experimentation on a new translucent passive solar wall combining silica aerogels and phase change materials
}

\author{
Yannick Berthou ${ }^{1}$, Pascal Henry Biwole ${ }^{1,2}$, Patrick Achard ${ }^{1}$, Hébert Sallée ${ }^{3}$, Mireille \\ Tantot-Neirac ${ }^{1}$ and Frédéric Jay ${ }^{4}$ \\ ${ }^{1}$ MINES ParisTech, PSL Research University, PERSEE - Center for Processes, Renewable Energies and \\ Energy Systems, F-06 904 Sophia Antipolis, France \\ ${ }^{2}$ Department of Mathematics and Interactions, J-A Dieudonné Laboratory, UMR CNRS 6621, University of \\ Nice Sophia-Antipolis, 06108 Nice, France \\ ${ }^{3}$ Scientific and Technical Centre for Building Research (CSTB), 24 rue J. Fourier, 38400 St-Martin \\ d'Hères, France \\ ${ }^{4}$ CRISTOPIA Energy Systems, 06140 Vence, France
}

Corresponding author: P. H. Biwole, Tel: +33 492965029, fax: +33 492965071, email:phbiwole@unice.fr

\begin{abstract}
This paper presents the first passive solar wall providing simultaneously super insulation, heat storage and daylighting to the inner space. The wall's external layer is composed of a silica aerogels bed for high insulation and solar radiation transmission. The second layer, internal, is composed of glass bricks filled with a eutectic phase change material (PCM) for heat storage and restitution. The whole wall is translucent. The experimentations carried out to characterize thermal and optical properties of the materials used are described. Then results are given for a full scale comparative experimentation on a twin zones building located in the south of France for the solar wall and a standard opaque high thermal capacity wall. Results show the heat losses through the wall are very low while the heat and light gains are high: The $U$ value of the solar wall is $0.59 \mathrm{~W} \cdot \mathrm{m}^{-1} \cdot \mathrm{K}^{-1}$ and $0.72 \mathrm{~W} \cdot \mathrm{m}^{-1} \cdot \mathrm{K}^{-1}$ respectively when the PCM is in liquid and solid state. With the test building in free floating condition, the temperature difference between the outdoor and indoor air provided by the wall is about $9^{\circ} \mathrm{C}$ in winter. The wall can provide up to 500 lux to the inner environment, which is sufficient for conference rooms. The tested wall has proven more effective in winter and shoulder season, particularly for cold sunny climates, but may cause overheating in summer.
\end{abstract}

Keywords: passive solar wall; phase change materials; silica aerogels; daylighting

\section{Introduction}


Buildings account for around $40 \%$ of the primary energy consumption worldwide (IEA, 2014) and 43\% in France (ADEME, 2014). To reduce this share, passive solar techniques have been investigated for decades. Among these, one of the most ancient is the Trombe wall, which principles were patented by Morse (1881). Trombe walls consist of an external glazing facing the winter sun, a few centimeters wide air channel, and a high heat capacitance wall in contact with the indoor environment (Trombe, 1973; Ohanessian and Charters, 1978). Thanks to the greenhouse effect within the air channel, they can reduce the energy bill by 20 to $30 \%$ virtually in all climates (Sebald et al., 1979; Krüger et al., 2013; Bojic et al., 2014), especially when the air gap is vented (Akbarzadeh et al.1982, Yanfeng et al. 2013). Among drawbacks often cited for Trombe walls, there are the cost, the delicate design and operation for the air gap and vents, and the absence of light transmission through the wall.

To overcome the latter and to enhance the Trombe wall heat storage performance, some researchers have replaced the high heat capacitance wall by phase change materials (PCM). Phase change materials store or release heat during their reversible solid - liquid or liquid gaz or solid - solid cycles. Due to their high latent heat, those materials have been extensively developped and used to enhance thermal inertia and delay heat release in various applications (Zalba et al., 2003) including buildings (Ahmad et al., 2006; Tyagi and Buddhi, 2007; Kuznik et al., 2011; Biwole et al., 2013). In 1978, Telkes (1978) showed the potential of replacing the regular masonry in Trombe walls by a Glauber salt PCM. The next year, Farouk and Guceri (1979) substituted the high heat capacitance wall by a Glauber salt mixture ( $\mathrm{Na2SO} 4.10 \mathrm{H} 2 \mathrm{O}$ ) and a P-116 wax to provide night-time heating. More recently, Fiorito (2012) did a parametric study on the use of PCM in Trombe walls by varying the PCM position and the melting point temperature for five different climates. All three teams found comparable or enhanced performances for the modified Trombe wall.

Zalewski et al. (2012) experimentally studied a Trombe wall with PCM components inside the air channel and an insulating panel instead of the high capacitance wall. Their system increased the heat storage capacity of the wall, prevented the air circulation inversion within the channel -phenomenon that can occur when the wall temperature becomes lower than the room temperature - but the light transmission was still absent. De Gracia et al. (2013) also studied an experimental Trombe wall with PCM during winter period. In their system, four vent shutters allowed the air to move from the exterior to the interior, thus providing both free ventilation and free heating of the building thanks to the natural convection in the channel. By closing the inner vents, they were also able to quicken the solidification process of the PCM. Yongcai and Shuli (2014) used the Trombe wall principle to design a solar chimney including a glazing and a PCM. 
The present paper investigates the behavior of an unvented Trombe wall composed of a super insulating silica aerogels layer later referred to as the Transparent Insulation Material (TIM) layer, and a PCM layer. Silica aerogels are highly insulating transparent materials with high porosity and pore size less than $1 \mu \mathrm{m}$ (Bisson, 2004). They are produced from the synthesis, ageing and drying of silica based colloids (Pajonk et al., 1995; Pierre and Pajonk, 2002; Dorcheh and Abbasi, 2008). Their transparency and insulation properties heavily depend on the process of their production (Pajonk et al., 1997; Rigacci et al. 1998). They have been searched for integration in buildings wallboard (Spaceloft, 2014), as external coating to suppress thermal bridges in retrofitting cases (Ibrahim et al., 2014) and to enhance the thermal insulation of double glazing windows (Rubin and Lampert, 1983; Reim et al., 2002; Schultz et al. 2005). They are also very good acoustic insulation materials due to their high sound absorptivity and a lower-than-air velocity of sound propagation (Hannoun et al., 1994; Gibiat et al., 1995; Forest et al., 2001).

The passive solar wall discussed in this paper is composed of a glass facing the outside, a gap filled with silica aerogel for light transmission, heat and sound insulation and for greenhouse effect, and glass bricks filled with an eutectic PCM for solar energy storage and thermal inertia. Section 2 describes the experimental wall. Section 3 presents the optical and thermal characterization of the chosen PCM, silica aerogel and also presents the full scale experimental building. Section 4 shows the results of the monitoring of the full scale wall under four different climate conditions. Finally, the wall's experimental behavior and performance are discussed in section 5 .

\section{System description}

The TIM-PCM wall presents a double layer design (Fig.1). The outer (TIM) layer is composed of a $4 \mathrm{~cm}$ gap formed between the bricks and a $0.8 \mathrm{~cm}$-large glass pane, filled with silica aerogel granulates. This layer is highly translucent and provides super-insulation. The inner layer is composed of glass bricks of dimension $19 \mathrm{~cm} \times 19 \mathrm{~cm} \times 5 \mathrm{~cm}$ filled with PCM. This layer is mainly designed to provide radiation absorption, energy storage, and daylighting. A wood frame maintains the system as a prefabricated assembly.

\section{Experimentations}

Experimentations were made at different scales of the system to fully apprehend its physical properties and behavior. First, silica aerogel and PCM thermal and optical properties were separately characterized. Then, a small sized TIM-PCM wall was experimented in 
laboratory conditions to study the whole system thermal and optical behavior. Finally, full scale in-situ experimentations were carried out on a double zone test cell in Sophia Antipolis, South France, in order to have a feed-back in real conditions.

\subsection{Material's characterization}

\section{Phase Change Material}

The PCM used in the TIM-PCM wall is an eutectic of fatty acids. The main advantages of this eutectic are a long-term stability throughout time and cycling processes, and a phase change at a comfortable temperature. The thermo-physical properties of the chosen PCM are shown in Table 1.

Enthalpy measurements using Differential Scanning Calorimetry (DSC) were made to fully characterize the PCM thermal properties, especially during phase change which is the most sensitive part of the process (See Fig. 2). The scanning speed of $0.05 \mathrm{~K}_{\mathrm{min}} \mathrm{m}^{-1}$ was set up as the standard temperature-change speed in buildings. The DSC curves show the PCM behavior during fusion and solidification processes. A slight difference appears between measured properties (summarized in Table 2) and previous theoretical properties (Table 1). Those differences are visible in the form of a hysteresis on Fig. 2 and can be explained by the lack of purity of the eutectic and the applied loads solicitations.

Since the TIM-PCM wall aims to absorb visible radiation and provide daylighting, optical measurements according to the EN410 norm were made to characterize the transparency of the PCM. The reflectance and transmittance for the energetic and optical parts of the radiation are measured for normal hemispheric, $15^{\circ}, 30^{\circ}$, and $45^{\circ}$ orientations of the incident beam directions. To do so, a $3 \mathrm{~cm}$ thick test tube was characterized while empty, and then characterized again when filled with PCM in solid and liquid states. The transmission and reflection coefficients $T_{n h}$ and $\rho_{n h}$, of the PCM alone, for a normal hemispheric incident radiation, are displayed in Table 3 . The measured properties fit the requirements of the wall in terms of absorption and transparency, since it absorbs $47 \%$ of the energetic radiation in solid state and transmits $78 \%$ of optical radiation in liquid state. The only shortcoming is that it cannot provide daylighting when in solid state. This is taken into account in the wall design, the transparent edges of the glass bricks contributing to provide daylighting.

\section{Silica aerogel}

A silica aerogel granulate bed is used to provide wall insulation and the same time ensure radiation transmission to the PCM layer. Its physical properties, taken from manufacturer' datasheet, are summarized in Table 4. Its energetic and optical transmissions were measured and compared with the manufacturer's data (see Fig. 3 for the energetic 
transmission). It was noted that the silica aerogel used in the TIM-PCM wall has a better transmission than it was expected (up to $20 \%$ more). Optical transmission is not reported here since values are similar to energetic transmission ones, meaning that the silica aerogel is opaque to low energy radiation (infra-red, excepted for a short transparent band, Fricke and Tillotson, 1997) and translucent to high energy radiation (in the visible wave-band, Duer and Svendsen, 1998). The choice of this particular silica aerogel, highly insulating and translucent, was made to meet the TIM-PCM wall's insulation and transparency criteria.

\subsection{The $1 \mathrm{~m}^{2}$ prototype}

To characterize thermal properties of the combined silica aerogels and phase change materials system, a small sized prototype $\left(1 \mathrm{~m}^{2}\right)$ was made. The prototype was placed on a heat exchanger test rig consisting of two vertical and parallel isothermal flat plates (see Fig. 4, fully described in Ahmad et al., 2006). The prototype was placed inside the rig and temperature loads were applied on both surfaces. Thermal resistances of the prototype were calculated from flux measurements in steady-state. Its R-value varied from 1.57 to 1.68 $\mathrm{m}^{2} \mathrm{~K} . \mathrm{W}^{-1}$ when the PCM was in solid state, and was $1.39 \mathrm{~m}^{2} \mathrm{~K}^{-\mathrm{W}^{-1}}$ when the PCM was in liquid state. A higher convection heat transfer is responsible for the lower resistance of the wall when the PCM is in liquid state. The $U$ value of the TIM-PCM wall is 0.59 and 0.72 W.m ${ }^{1} . \mathrm{K}^{-1}$ respectively when the wall is in liquid and solid state.

The MEGASPHERE test rig of the French Scientific and Technical Centre for Building Research (CSTB Grenoble, France) was used to characterize the optical properties (light reflection, transmission and absorption) of the prototype (Fig. 5). Energetic and optical transmissions $\tau_{\mathrm{enh}}$ and $\tau_{\mathrm{vnh}}$ were extrapolated from spectral transmission curves acquired for 300 to $2500 \mathrm{~nm}$ wavelengths according to the EN410 norm. Reflections $\rho_{\text {enh }}$ and $\rho_{\text {vnh }}$ were directly measured by a wide angle sensor.

From Table 5, it appears that the absorption of the prototype is high when the PCM is in liquid state. It means that the wall can easily store sensible heat, which may have a negative impact on the general ambiance within the building in summer by increasing its temperature. The light absorption is lower when the PCM is in solid state, meaning that only a part of incident solar radiation can be stored. This does not diminish the efficiency of the wall in warm Mediterranean climates such as of South France, as seen in the in situ results.

\subsection{The full-scale experiment}

The TIM-PCM wall was tested in situ in a full-scale building in Southern France. The building has a light frame architecture, is highly insulated (the R-value varies from 4.7 to 6.8 $\mathrm{m}^{2} . \mathrm{K} \mathrm{W}^{-1}$ ) and is composed of three rooms (Fig. 6). Both South facing rooms are identical 
(same wall properties, $9.2 \mathrm{~m}^{2}$ floor area) except for their South facing walls. The test room is equipped with $4.41 \mathrm{~m}^{2}$ of TIM-PCM wall facing south while the reference room is equipped with a $7.15 \mathrm{~m}^{2}$ high capacitance opaque wall. The high capacitance (reference) wall is made, from outside to inside, of concrete, glass wool thermal insulation, and plaster. The thermophysical properties of the reference wall are given in Table 6. The third room, facing North $\left(18.8 \mathrm{~m}^{2}\right)$, is used for data acquisition purpose. The building is left in free floating conditions without internal heat gains.

A specific instrumentation is used to collect the necessary data to calculate the convection, conduction and radiation heat exchanges between the two south facing walls and their inside and outside environments. Surface temperatures are measured with PT100 sensors (Prosensor Pt 100 DIN IEC 751 class B) of precision $\pm 0.4^{\circ} \mathrm{C}$. The sensors are protected from radiation by aluminum sheets. Temperatures inside the TIM-PCM wall (in the silica aerogel bed and within the bricks containing the PCM) are measured with PT100 (Prosensor SLM 250 PVC).

Total radiation on the horizontal plan is measured with a pyranometer (Pulsonic, 400$1100 \mathrm{~nm}$ ) of precision $\pm 4 \%$ of the read value. Total radiation on the vertical plan is measured with a second pyranometer (Littoclime 13S374, 320-1060 nm) of precision $\pm 7 \%$ of the value. Wind direction and velocity are measured by wind vane and anemometer (Pulsonic Aliza 147) of precision $\pm 0.5 \mathrm{~m} / \mathrm{s}$. Air temperature and relative humidity for the outside atmosphere and for both rooms are measured by all-in-one sensors (Prosensor HYGR0018 THAC, with added radiation protection) of precision $\pm 0.4^{\circ} \mathrm{C}$ for temperature and $\pm 3 \%$ of the read value for relative humidity. Two double range lux meters (Littoclime 13G134, 0-10 klux and 0-100 klux) of precision $\pm 5 \%$ of the value, are used to measure the outside and inside global horizontal illuminance (light intensity) and to characterize the daylighting provided by the TIM-PCM wall.

To prevent breaking from thermal expansion of the PCM, the bricks were initially filled with the PCM at a temperature of $50^{\circ} \mathrm{C}$ and an air gap of $2 \mathrm{~cm}$ was left on top of the liquid surface inside each brick.

\section{Results}

\subsection{Meteorological data}

The TIM-PCM wall has been monitored from December to March and during the month of August. These periods cover most typical weathers of a year in Sophia-Antipolis, South France: cold and short days (December to February), shoulder season (March) and hot long days (August). A Summary of the meteorological data for the TIM-PCM wall experimentation is given in Table 7. All data were acquired with a 5 min time step. The maximum radiation 
measured on a vertical plan is higher during the cold months, coinciding with the period when the heat gains through the wall are wanted. Trees in the vicinity of the test building causes shading on the studied walls, especially on early morning, midday and late afternoon in winter and shoulder seasons, which temporary limits solar gains. Three consecutive days of each mentioned periods were studied and the results are presented hereafter.

\subsection{Heat gains}

Heat gains provided by the TIM-PCM wall have a convective part and a long wave radiation part and are both derived from temperature measurements. The convective part is calculated from the mean surface temperature of the TIM-PCM wall and the air temperature inside the test room. The radiative part is calculated from the mean surface temperature of the TIM-PCM wall and the mean surface temperatures of every surface inside the test room. Fig. 7 presents the experimental results for the heat gains through the reference and the TIM-PCM walls and solar radiation for the four specific climate cases.

For each study case, the heat flux entering the reference room through the standard opaque wall is almost constant and very low: $-5 \mathrm{~W} \cdot \mathrm{m}^{-2}$ in winter and shoulder season and +5 W. $\mathrm{m}^{-2}$ in summer. Regarding the TIM-PCM wall, a time lag of more than 4 hours is always observed. Its behavior through hours, days and seasons depends a lot on the following typical weather conditions.

- Weather condition 1: Three consecutive cold days with high solar radiation (Fig. 7.1)

Those days are characterized by a solar radiation on the south facing vertical plane of about $800 \mathrm{~W} \cdot \mathrm{m}^{-2}$ at noon and an outdoor air temperature ranging from 7 to $18^{\circ} \mathrm{C}$. Three dynamics for the heat release through the TIM-PCM wall are observed. The first one, starting at sunrise, corresponds to the heating and the melting of the solid PCM. Then a release of latent heat for about 14 hours (which is consistent with De Gracia et al., 2013) starting around $4 \mathrm{pm}$ occurs at an almost constant value of $50 \mathrm{~W} \cdot \mathrm{m}^{-2}$. When the PCM is totally solidified, the PCM is cooled down and sensible heat is released (steeply decreasing slopes). This case is appropriate for high TIM-PCM wall performances. The recorded indoor air temperature varied from 17 to $20^{\circ} \mathrm{C}$, and was always higher than that of the reference room by $1^{\circ} \mathrm{C}$ to $3.5^{\circ} \mathrm{C}$ as shown on Fig. 8.1.

- Weather condition 2: Three consecutive winter days with low solar radiation (Fig. 7.2)

On those days, the maximum recorded amount of solar radiation on the south facing vertical plane is $130 \mathrm{~W} . \mathrm{m}^{-2}$ and the outdoor temperature varies from 4 to $11^{\circ} \mathrm{C}$. The $\mathrm{PCM}$ 
always stays in solid state. There is almost no absorbed nor released heat and some heat losses less than $5 \mathrm{~W} \cdot \mathrm{m}^{-2}$ appear through the TIM-PCM wall at night. Here, the TIM-PCM wall does not bring any improvement when compared to the reference opaque wall. The recorded indoor air temperature varied from 11 to $14^{\circ} \mathrm{C}$.

- Weather condition 3: Three consecutive shoulder season days with high solar radiation (Fig. 7.3)

Here, the maximum solar radiation is $750 \mathrm{~W} \cdot \mathrm{m}^{-2}$ and the outdoor air temperature varies from 8 to $25^{\circ} \mathrm{C}$. The PCM is always in a melting or in a solidifying process. During nights and days, the entering flux is stabilized at an almost constant value of $50 \mathrm{~W} \cdot \mathrm{m}^{-2}$. This case represents the best case for the stabilization from the flux point of view but neither the fusion nor the crystallization can be fully achieved. Overheating of the room can be observed on some warm days.

- Weather condition 4: Three consecutive summer days (Fig. 7.4)

Those days are characterized by a solar radiation on the south facing vertical plane of about 500W. $\mathrm{m}^{-2}$ at noon and an outdoor air temperature ranging from 23 to $40^{\circ} \mathrm{C}$. Even if the solar radiation on the vertical plan is lower in summer, air temperatures are too high to allow even partial solidification of the PCM at night. During the day, the PCM's temperature strongly increases resulting in a high sensible heat release. These heat gains generate overheating of the building, with indoor air temperature ranging from 35 to $40^{\circ} \mathrm{C}$ as shown on Fig. 8.2. These temperatures exceed that of the reference room by 2 to $6^{\circ} \mathrm{C}$. Shading and night ventilation should be used in order to prevent this scenario.

An efficiency parameter, calculated as the ratio between the solar radiation received by the TIM-PCM wall and the total heat gains provided by the wall can be assessed for each studied month. Mean effectiveness is about $35.2 \%$ (36.8 \% in December, $33.7 \%$ in January, $37.5 \%$ in February and $32.9 \%$ in March). For August, this parameter is of no interest since heat gains are not wanted. It should be noted that since the building is in free floating conditions, the inside air temperature variations impact directly this parameter.

\subsection{Daylighting}

One of the TIM-PCM wall functions is to provide visual comfort through daylighting. From the results, two cases are of interest. The first one occurs when the PCM is in solid state or in solid/liquid state (winter and shoulder seasons when the radiation on vertical plan is 
higher). The second one occurs when the PCM is in liquid state (summer and shoulder seasons when the radiation on vertical plan is lower).

Fig. 9 shows pictures of the daylighting provided by the TIM-PCM wall when the PCM is in solid state and when it is in liquid state. Inside the test room, the lux meter is situated one meter behind the middle of TIM-PCM wall and one meter above the floor level. When the PCM is in solid state, a maximum of $3 \mathrm{klx}$ is provided by the wall, corresponding to a daylight factor of $3.4 \%$, as shown on Fig.10. According to European norm EN12464, such values are acceptable for various spaces such as warehouses, roofed parking lots, corridors, restrooms or waiting rooms. Since the solid PCM is almost opaque, most of the light comes from the translucent edges of glass bricks. When the PCM is in liquid state, the wall provides up to 5 $\mathrm{klx}$ which corresponds to a daylight factor of $6.7 \%$. According to EN12464 norm, such values are acceptable for offices, classrooms, conference rooms, kitchens and certain workshops. Here, the light comes from both the liquid PCM and the glass bricks' edges. Artificial lighting is still necessary as back up to reach lighting requirements all day long, regardless of the fluctuation of natural light.

\section{Conclusions and outlooks}

Experimentations have been carried out to study the design of a TIM-PCM passive solar wall consisting of a glass facing the outside, a silica aerogel bed for thermal/sound insulation and light transmission, and a PCM in glass bricks for energy storage and release. The first step consisted in thermal and optical characterizations of the silica aerogels and phase change materials. The results have shown a good capability for these materials to reach the expected goals: the chosen silica aerogels are highly insulating and translucent and the PCM can successfully achieve its role of energy absorption, high capacity storage, constant heat restitution and daylighting when in liquid state. Then, a $1 \mathrm{~m}^{2}$ prototype was studied and the effectiveness of the wall in terms of heat absorption and translucency was confirmed. Finally, a full-scale experimentation carried out in the South of France has given a good understanding of its behavior.

The TIM-PCM wall can contribute to the insulation, the heating and the daylighting of the test room. The $U$ value of the TIM-PCM wall is 0.59 and $0.72 \mathrm{~W} \cdot \mathrm{m}^{-1} \cdot \mathrm{K}^{-1}$ respectively when the wall is in liquid and solid state. The temperature difference between the outdoor and indoor air provided by the wall is up to $10^{\circ} \mathrm{C}$ in winter. The wall can provide a daylight factor up to $6.7 \%$ to the inner environment. It was seen that the PCM absorbs and stores a lot of heat at a constant temperature. The release of latent heat, constant, is made with a time lag of about 
4 hours. The translucent silica aerogel bed provides high insulation and daylighting. Its filtering role, letting high energy radiation going to the PCM and blocking low energy radiation from the PCM, contributes to the effectiveness of the wall. Five years after its construction, no deterioration of the PCM or the silica aerogels has been noted and the TIM-PCM wall is still acting the same way. Especially, a cycling of the PCM is still observed.

By providing heat gains and daylighting, the TIM-PCM wall has a great potential for energy savings in buildings in winter and shoulder seasons for sunny climates. However, it was noted that when the solar radiation is very low, the wall does not bring any additional heat. In summer, the PCM does not cycle and stays in liquid state. Then the heat gains through the TIM-PCM wall have a negative impact on the indoor conditions, by rising the room's temperature. Night ventilation to evacuate extra heat and the use of shadings to limit solar heat gains could be used to limit such drawbacks. In the future, the TIM-PCM wall could also contribute to maintain the room temperature low in summer time, provided the cycling of the PCM is achieved. Further research should be devoted to that prospect.

\section{Acknowledgements}

This work was supported by a funding from the French National Research Agency (ANR) and the French Environment and Energy Management Agency (ADEME) through the PREBAT INERTRANS project. The authors would like to thank those two agencies for their support and all the members of the project consortium having permitted all together the achievement of the work presented.

\section{References}

Ahmad, M., Bontemps, A., Sallée, H., Quenard, D., 2006. Experimental investigation and computer simulation of thermal behaviour of wallboards containing a phase change material. Energy and Buildings 38, 4, 357-366.

Akbarzadeh, A., Charters, W.W.S., Lesslie, D.A., 1982. Thermocirculation characteristics of a Trombe wall passive test cell Solar Energy Volume 28, 6, 461-468.

Bisson, A., 2004. Synthese et etude de materiaux nanostructures a base de silice pour la superisolation thermique, PhD. Thesis, Mines de Paris.

Biwole, P.H., Eclache, P., Kuznik, F., 2013. Phase-change materials to improve solar panels 
performance. Energy and Buildings 62, 59-67.

Dorcheh, A. S., Abbasi, M. H., 2008. Silica aerogel; synthesis, properties and characterization. Journal of Materials Processing Technology199, 10-26.

Bojic, M., Johannes, K., Kuznik, F., 2014. Optimizing energy and environmental performance of passive Trombe wall. Energy \& Buildings 70, 279-286.

De Gracia, A., Navarro, L., Castell, A., Ruiz-Pardo, Á., Alvárez, S., Cabeza, L. F., 2013. Experimental study of a ventilated facade with PCM during winter period. Energy and Buildings 58, 324-332.

Duer, K., Svendsen, S., 1998. Monolithic silica aerogel in superinsulation glazings, Solar Energy 63, 259-267.

Fiorito, F., 2012. Trombe Walls for Lightweight Buildings in Temperate and Hot Climates. Exploring the Use of Phase-change Materials for Performances Improvement. Energy Procedia 30, 1110-1119.

Forest, L., Gibiat, V., Hooley, A., 2001. Impedance matching and acoustic absorption in granular layers of silica aerogels, Journal of Non-Crystalline Solids 285, 230-235.

ADEME (French Environment and Energy Management Agency), retrieved March 5, 2014, from http://www2.ademe.fr/servlet/KBaseShow?sort=-1\&cid=96\&m=3\&catid=12846

Fricke J., Tillotson, T., 1997. Aerogels: production, characterization, and applications, Thin Solid Films 297, 212-223.

Gibiat, V., Lefeuvre, O., Woigniert, T., Pelous, J., Phalippou, J., 1995. Acoustic properties and potential applications of silica aerogels, Journal of Non-Crystalline Solids 186, 244 255.

Hannoun, P., Gibiat, V., Woygnier, T., Pelous, J., 1994. Mesures de vitesses acoustiques dans les aerogels de silice, Journal de physique IV, Colloque C5, Supplément au journal de Physique III, C5, 229-232.

Ibrahim, M., Biwole, P., Wurtz, E., Achard, P., 2014. Limiting Windows Offset Thermal Bridge Losses Using a New Insulating Coating, Applied Energy 123, 220-231.

IEA (International Energy Agency), retrieved March 5, 2014, from http://www.iea.org/topics/energyefficiency/buildings/

Krüger, E., Suzuki, E., Matoski, A., 2013. Evaluation of a Trombe wall system in a subtropical location. Energy and Buildings 66, 364-372.

Kuznik, F., David, D., Johannes, K., Roux, J.J., 2011. A review on phase change materials integrated in building walls. Renewable and Sustainable Energy Reviews 15, 379-391.

Morse, E.L., 1881. Warming and Ventilating Apartments by Sun's Rays, U.S. Patent 246, 626.

Ohanessian, P., Charters, W.W.S., 1978. Thermal simulation of a passive solar house using a Trombe-Michel wall structure. Solar Energy 20, 275-281. 
Pajonk, G. M., Elaloui, E., Achard, P., Chevalier, B., Durant, M., 1995. Physical properties of silica gels and aerogels prepared with new polymeric precursors. Journal of nonCrystalline Solids 86, 1-8.

Pajonk, G. M., Elaloui, E., Chevalier, B., Begag, R., 1997. Optical transmission properties of silica aerogels prepared from polyethoxidisiloxanes, Journal of non-Crystalline Solids 210 , 224-231.

Pierre, A. C., Pajonk, G.M., 2002. Chemistry of aerogels and their applications, Chemical Review 102, 4243-4265.

Rigacci, A., Achard, P., Ehrburger-Dolle, F., Pirard, R., 1998. Structural investigation in monolithic silica aerogels and thermal properties, Journal of non-Crystalline Solids 225, 260-265.

Reim, M., Beck, A., Körner, W., Petricevic, R., Glora, M., Weth, M., Schliermann, T., Fricke,J, Schmidt, C., Pötter, F.J., 2002. Highly insulating aerogel glazing for solar energy usage, Solar Energy 72, 21-29.

Rubin, M., Lampert, C.M., 1983. Transparent silica aerogels for window insulation, Solar Energy Materials 7, 4, 393-400.

Schultz, J.M., Jensen, K.I., Kristiansen, F.H., 2005. Super insulating aerogel glazing, Solar Energy Materials \& Solar Cells 89, 275-285.

Sebald, A.V., Clinton, J.R., Langenbacher, F., 1979. Performance effects of Trombe wall control strategies Solar Energy 23, 6, 479-487.

Spaceloft ${ }^{\circledR}$ Safety Data Sheet, Retrieved March 5, 2014, from http://www.aerogel.com/products/pdf/Spaceloft_MSDS.pdf.

Telkes, M., 1978. Trombe wall with phase change storage material. In: Proceedings of the 2nd National Passive Solar Conference, Philadelphia, PA, USA.

Trombe, F., 1973. Heating by solar radiation. CNRS Internal Report B-1-73-100.

Tyagi, V.V., Buddhi, D., 2007. PCM thermal storage in buildings: A state of art. Renewable and Sustainable Energy Reviews 11, 6, 1146-1166.

Yanfeng, L., Dengjia, W., Chao M., Jiaping, L., 2013. A numerical and experimental analysis of the air vent management and heat storage characteristics of a trombe wall. Solar Energy 91, 1-10.

Yongcai, L., Shuli, L., 2014. Experimental study on thermal performance of a solar chimney combined with PCM. Applied Energy 114, 172-178.

Zalba, B., Marín, J., Cabeza, L. F., Mehling, H., 2003. Review on thermal energy storage with phase change: materials, heat transfer analysis and applications. Applied Thermal Engineering 23, 3, 251-283.

Zalewski, L., Joulin, A., Lassue, S., Dutil, Y., Rousse, D., 2012. Experimental study of smallscale solar wall integrating phase change material. Solar Energy 86, 208-219. 


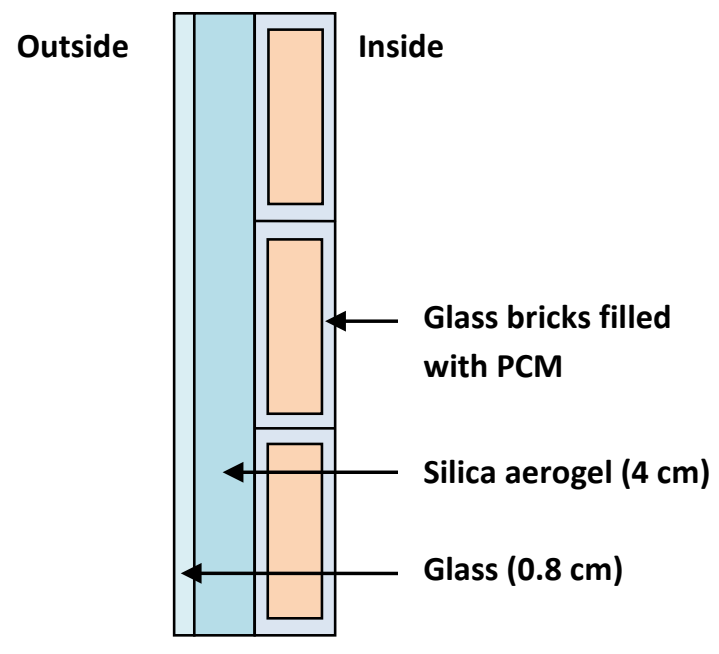

Fig. 1. TIM-PCM wall layout

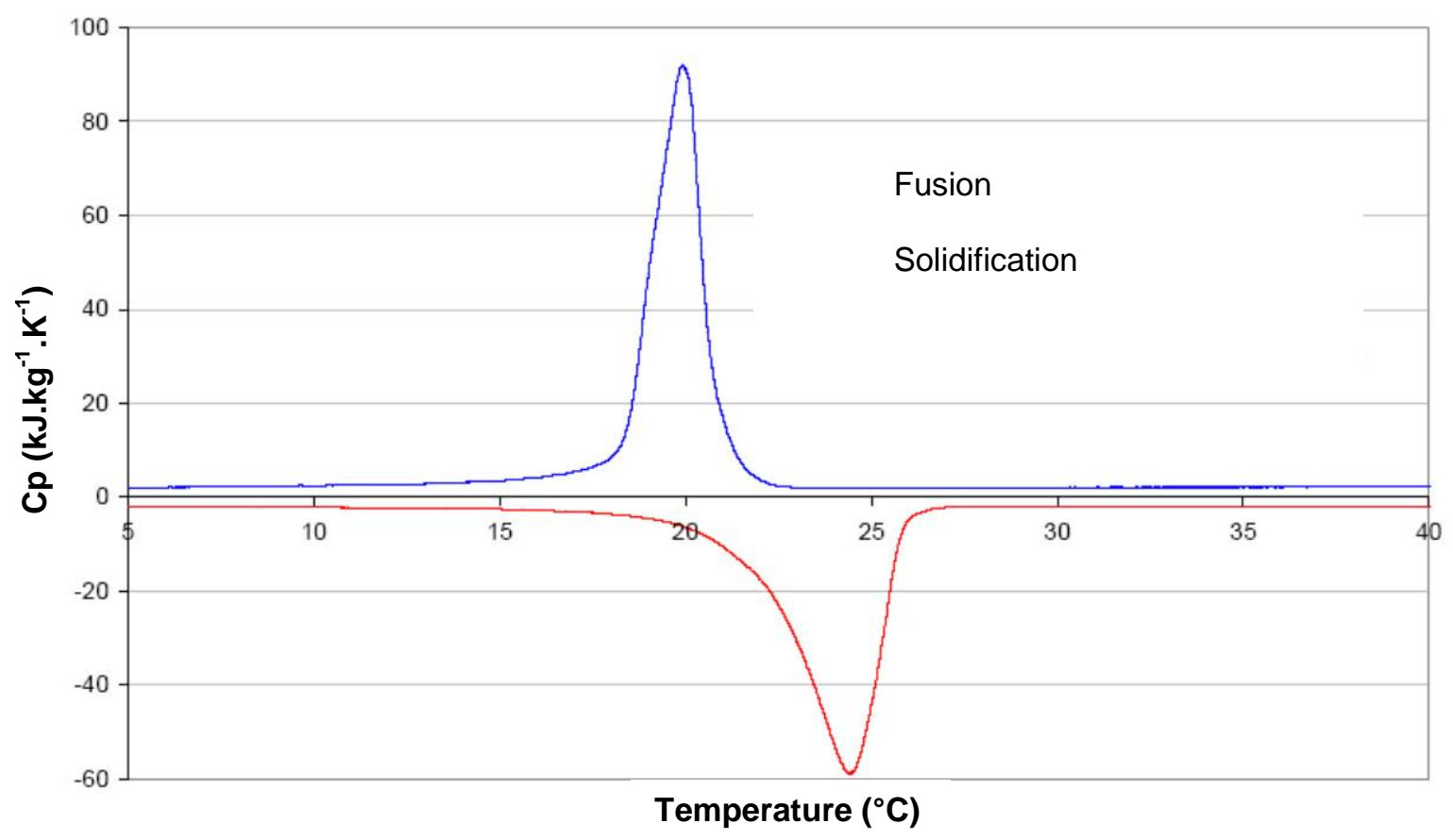

Fig. 2. Selected fatty acids eutectic phase change enthalpy measurements using DSC 


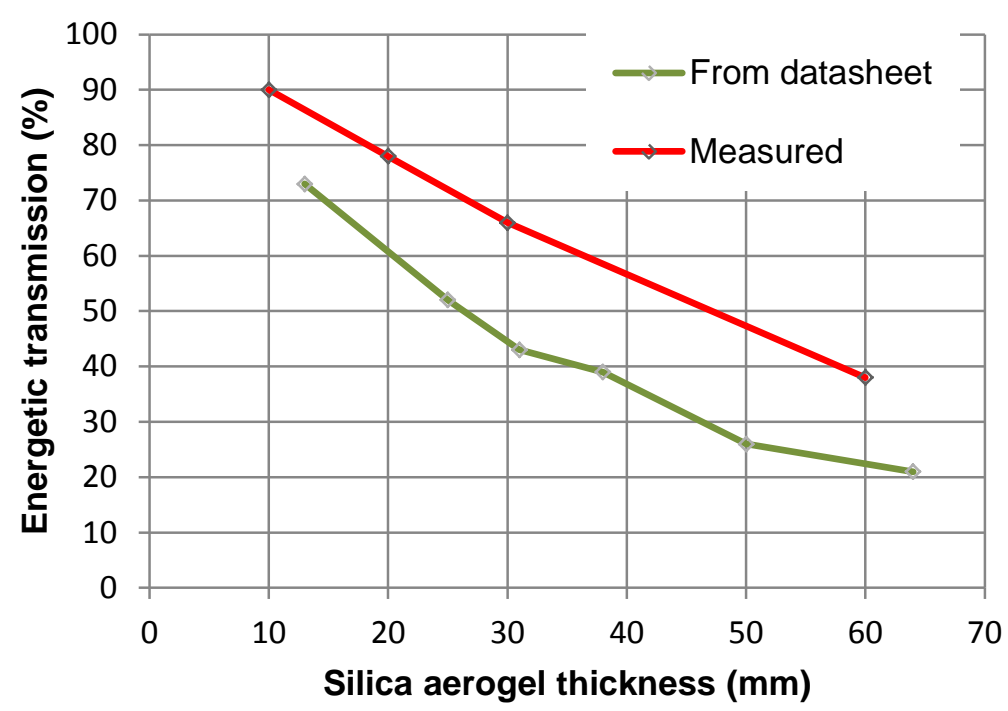

Fig. 3. Measured energetic transmission of a silica aerogel bed compared to manufacturer's data

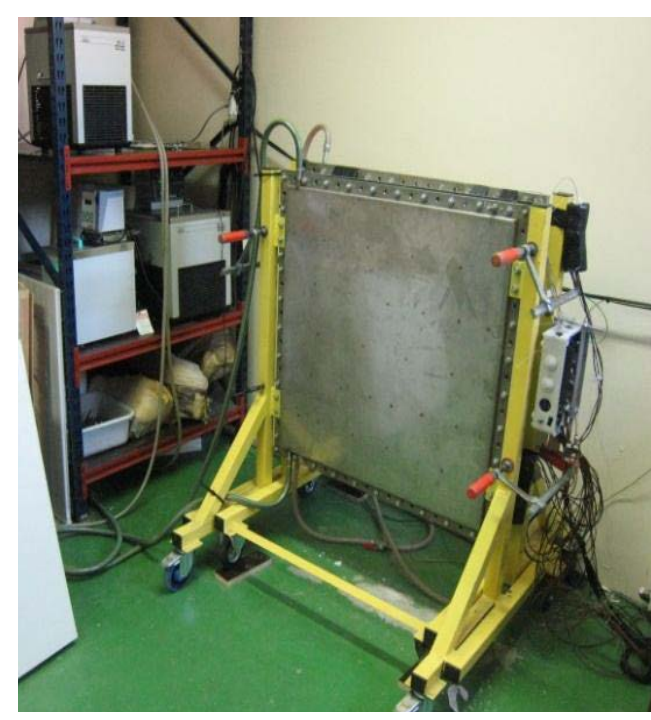

Fig. 4. Small size prototype within the double heat exchanger test rig 


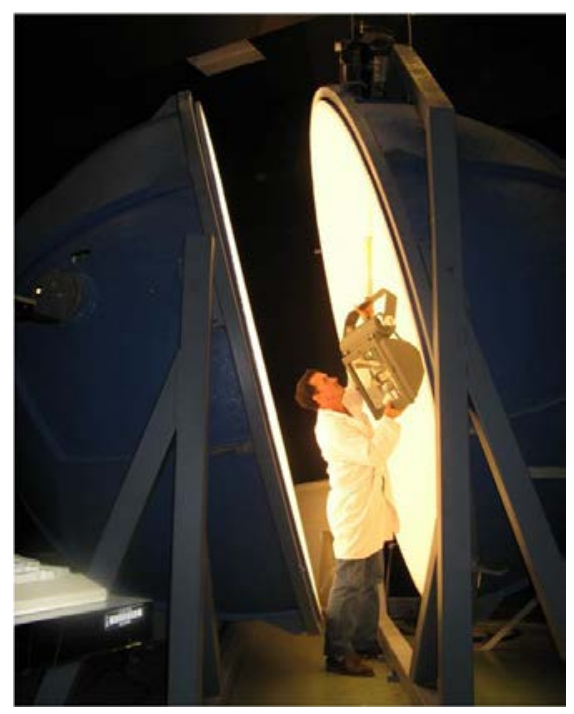

Fig. 5. Prototype installation in the MEGASPHERE at CSTB Grenoble

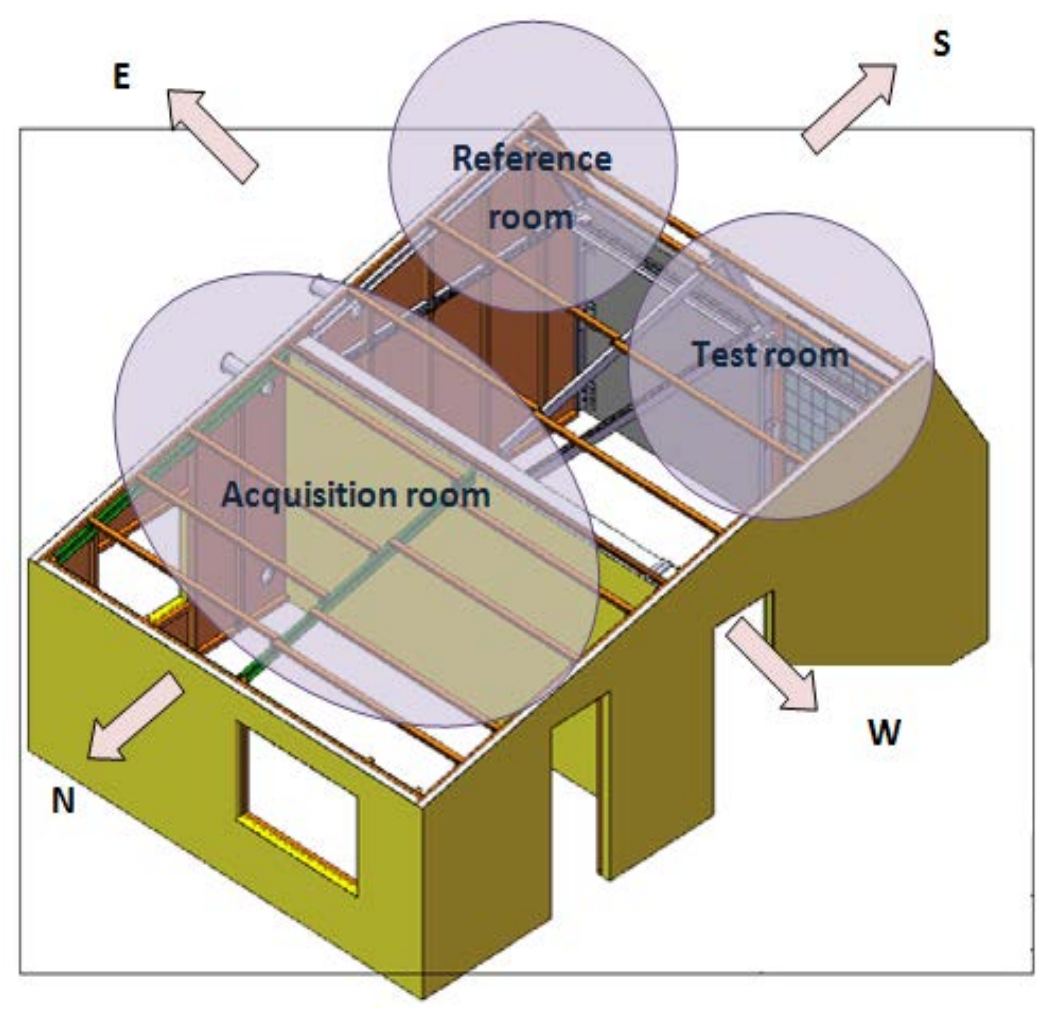

Fig. 6. Schematic presentation of the double zone test cell 


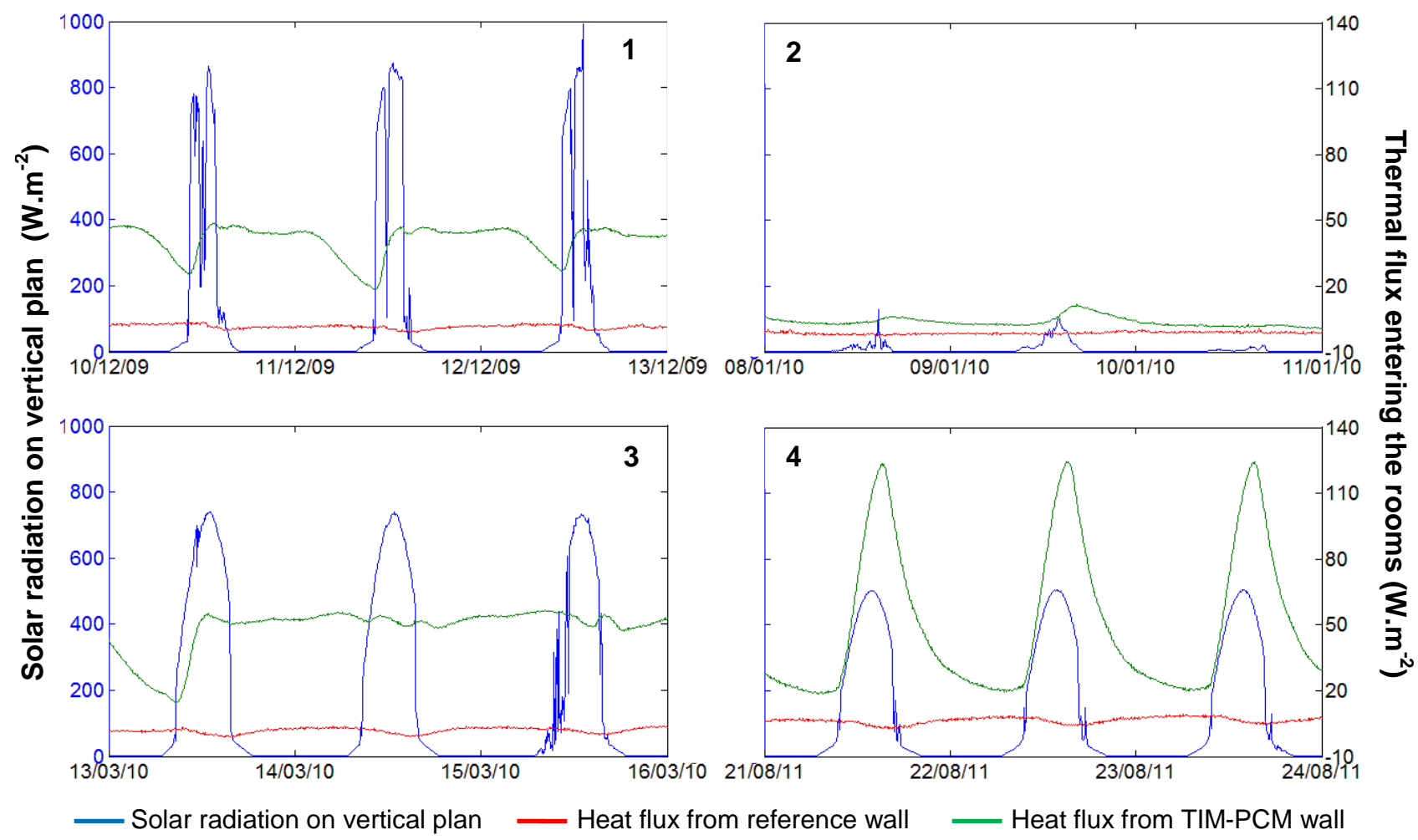

Fig. 7. Heat gains through the reference and the TIM-PCM walls and solar radiation for the four specific climate conditions

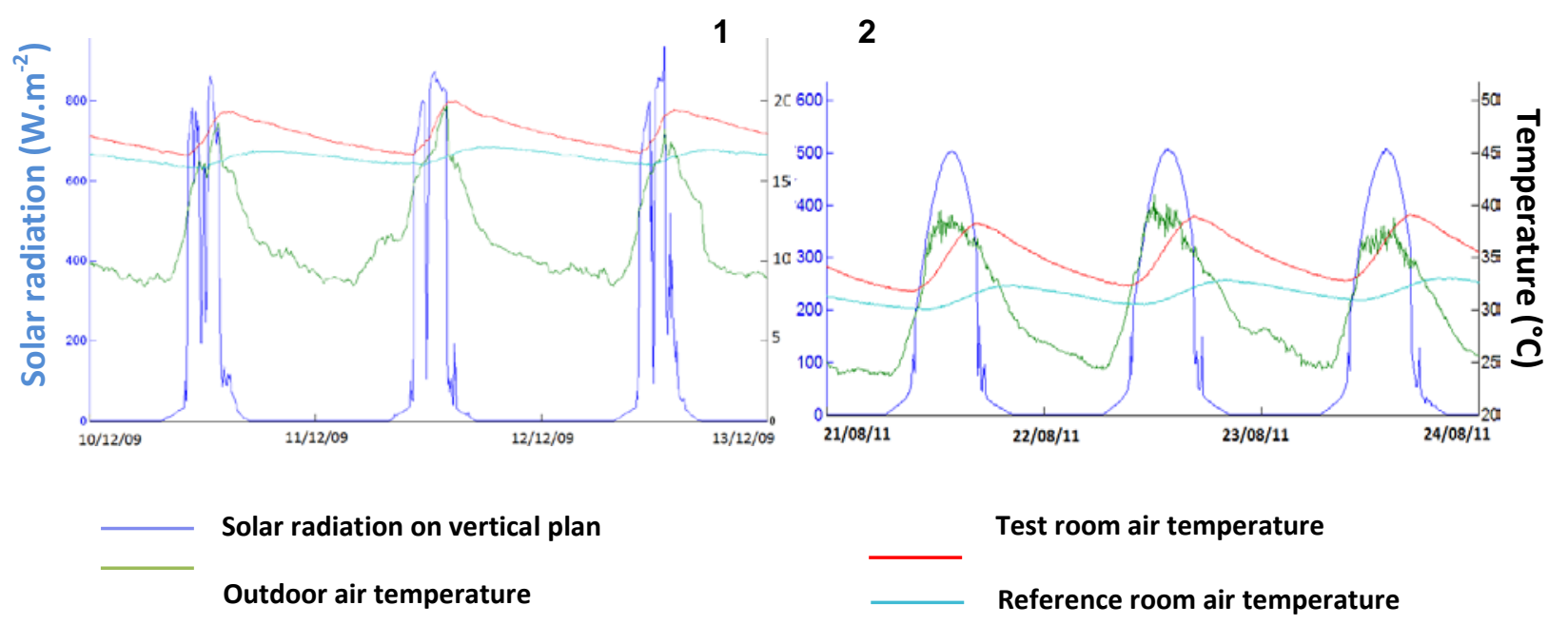

Fig. 8. Solar radiation and air temperatures for three days in December and August 

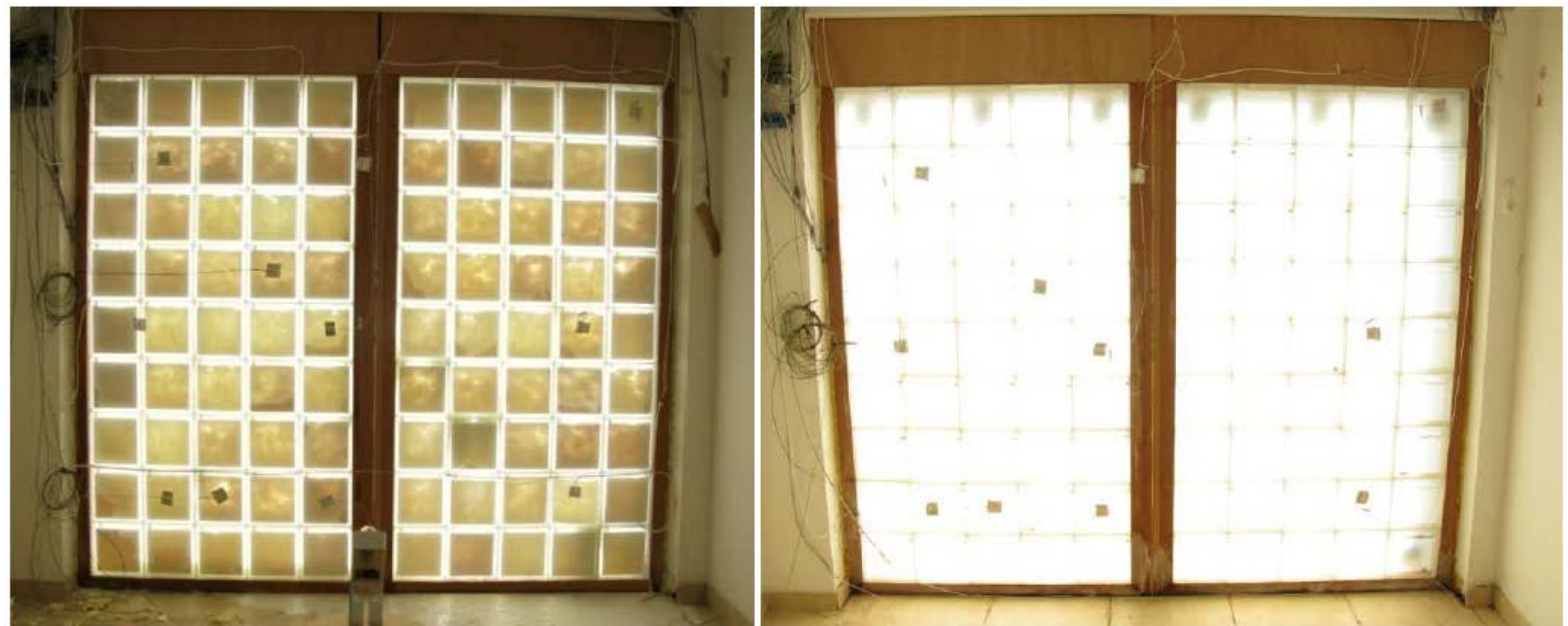

Fig. 9. Daylight provided by the TIM-PCM wall with the PCM in solid state (left) and liquid state (right). The picture is taken from inside the test room

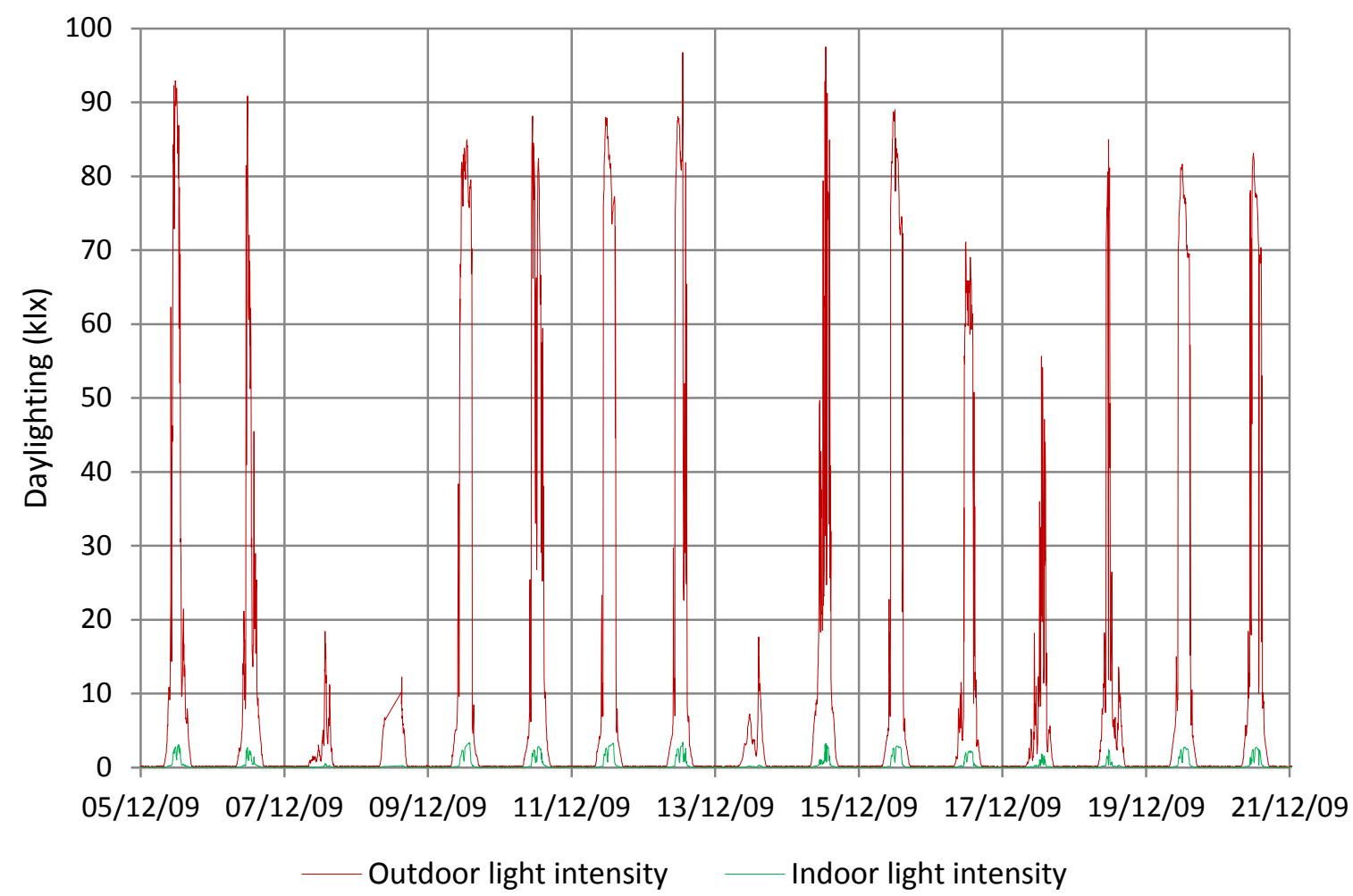




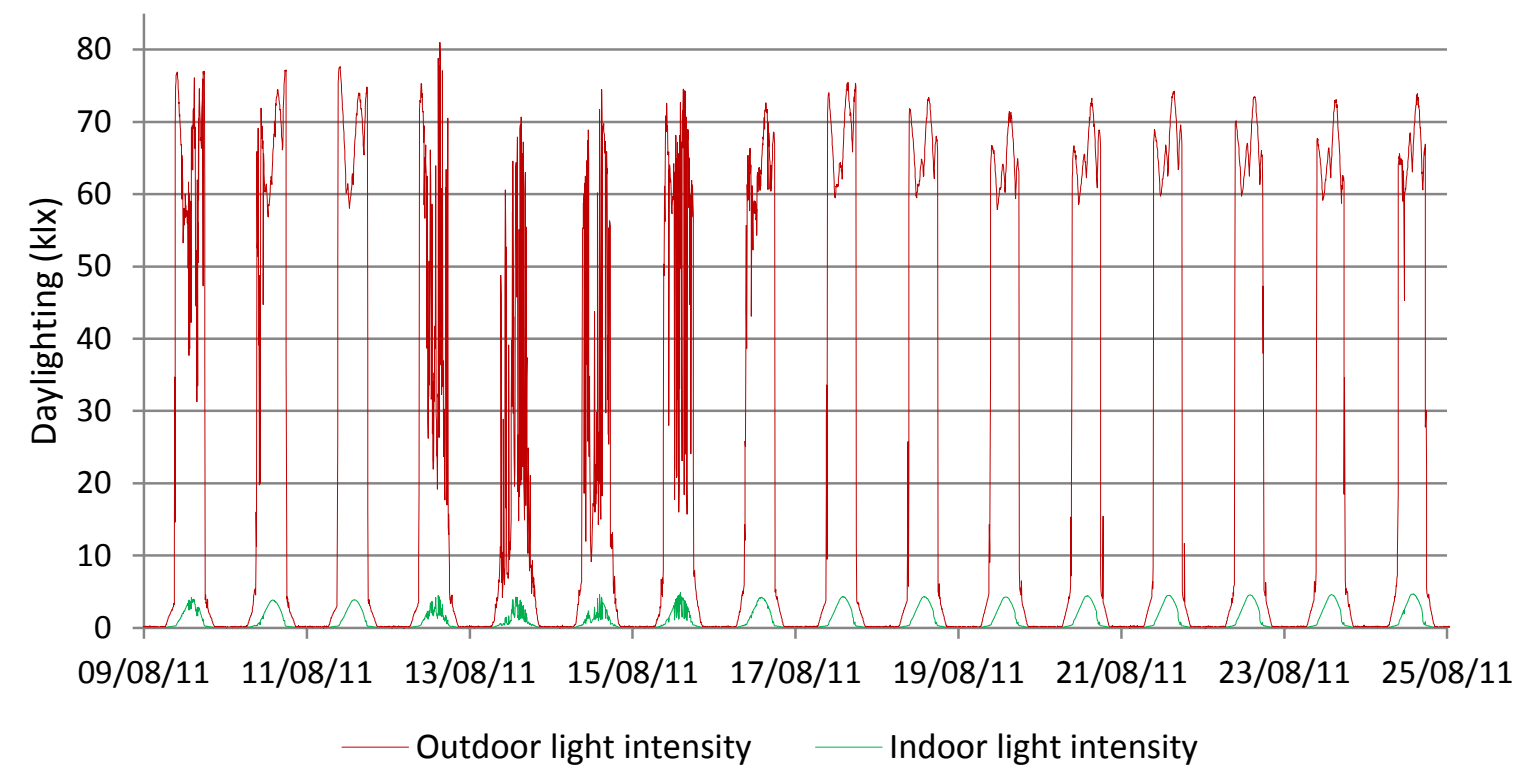

Fig. 10. Measurements of the daylighting outdoor and within the test room for 16 days in December and August

Table 1. Thermo physical properties of the eutectic used (manufacturer' data)

\begin{tabular}{lc}
\hline Phase change temperature & $\mathbf{2 1 . 3}{ }^{\circ} \mathrm{C}$ \\
\hline Phase change enthalpy & $152 \mathrm{~kJ} \cdot \mathrm{kg}^{-1}$ \\
Heat capacity (solid) & $1670 \mathrm{~J} \cdot \mathrm{kg}^{-1} \cdot \mathrm{K}^{-1}$ \\
Heat capacity (liquid) & $2090 \mathrm{~J} \cdot \mathrm{kg}^{-1} \cdot \mathrm{K}^{-1}$ \\
Density (solid) & $884 \mathrm{~kg} \cdot \mathrm{m}^{-3}$ (at $\left.35^{\circ} \mathrm{C}\right)$ \\
Density (liquid) & $960 \mathrm{~kg} \cdot \mathrm{m}^{-3}$ (at $\left.13^{\circ} \mathrm{C}\right)$ \\
Thermal conductivity (solid) & $0.182 \mathrm{~W} \cdot \mathrm{m}^{-1} \cdot \mathrm{K}^{-1}$ (at $\left.5,4^{\circ} \mathrm{C}\right)$ \\
Thermal conductivity (liquid) & $0.182 \mathrm{~W} \cdot \mathrm{m}^{-1} \cdot \mathrm{K}^{-1}\left(\right.$ at $\left.39^{\circ} \mathrm{C}\right)$ \\
Max working temperature & $70{ }^{\circ} \mathrm{C}$ \\
\hline
\end{tabular}

Table 2. Thermal properties of the PCM, measured by DSC

\section{Fusion Solidification}

\begin{tabular}{cccccc}
\hline Enthalpy $\left(\mathrm{kJ} . \mathrm{kg}^{-1}\right)$ & Begins at $\left({ }^{\circ} \mathrm{C}\right)$ & $\operatorname{Max}\left({ }^{\circ} \mathrm{C}\right)$ & Enthalpy $\left(\mathrm{kJ} . \mathrm{kg}^{-1}\right)$ & Begins at $\left({ }^{\circ} \mathrm{C}\right)$ & $\operatorname{Max}\left({ }^{\circ} \mathrm{C}\right)$ \\
161.8 & 22.2 & 24.6 & 161.1 & 21.0 & 19.9 \\
\hline
\end{tabular}


Table 3. PCM energetic and optical normal hemispheric transmission and reflexion

\begin{tabular}{|l|c|c|c|}
\cline { 3 - 4 } \multicolumn{2}{c|}{} & $\mathbf{T}_{\mathrm{nh}}$ (\%) & $\boldsymbol{\rho}_{\mathrm{nh}}$ (\%) \\
\hline \multirow{2}{*}{ Liquid state } & Energetic & 90 & 5 \\
\cline { 2 - 4 } & Optical & 78 & 6 \\
\hline \multirow{2}{*}{ Solid state } & Energetic & $\approx 0$ & 53 \\
\cline { 2 - 4 } & Optical & $\approx 0$ & 56 \\
\hline
\end{tabular}

Table 4. Physical properties of the silica aerogel (manufacturer' data)

\begin{tabular}{lc}
\hline Particle size & 0.5 to $4.0 \mathrm{~mm}$ \\
\hline Pore diameter & $20 \mathrm{~nm}$ \\
Porosity & $>90 \%$ \\
Surface area & 600 to $800 \mathrm{~m}^{2} \cdot \mathrm{g}^{-1}$ \\
Density & 90 to $100 \mathrm{~kg} \cdot \mathrm{m}^{-3}$ \\
Thermal conductivity & $0.018 \mathrm{~W} \cdot \mathrm{m}^{-1} \cdot \mathrm{K}^{-1}$ (at $\left.25^{\circ} \mathrm{C}\right)$ \\
\hline
\end{tabular}

Table 5. Energetic and optical transmission and reflection coefficients of the PCM-TIM $1 \mathrm{~m}^{2}$ prototype

\begin{tabular}{ccc}
\hline & energetical (EN 410) & optical (EN 410) \\
\hline$T_{n h}$ solid & $6 \%$ & $8 \%$ \\
$T_{n h}$ liquid & $31 \%$ & $35 \%$ \\
$\rho_{n h}$ solid & $62 \%$ & $72 \%$ \\
\hline$\rho_{n h}$ liquid & $8 \%$ & $10 \%$ \\
\hline
\end{tabular}

Table 6. Thermo-physical properties of the reference wall

\begin{tabular}{ccccc}
\hline $\begin{array}{c}\text { Materials } \\
\text { (from } \\
\text { outside to } \\
\text { inside) }\end{array}$ & $\begin{array}{c}\text { Width } \\
\mathbf{( m )}\end{array}$ & $\begin{array}{c}\text { Thermal } \\
\text { conductivity } \\
\left(\mathbf{W} \cdot \mathbf{m}^{-1} \cdot \mathbf{K}^{-1}\right)\end{array}$ & $\begin{array}{c}\text { Specific } \\
\text { heat } \\
\left(\mathbf{J} \cdot \mathbf{k g}^{-1} \cdot \mathbf{K}^{-1}\right)\end{array}$ & $\begin{array}{c}\text { Density } \\
\left(\mathbf{k g} \cdot \mathbf{m}^{-3}\right)\end{array}$ \\
\hline Concrete & 0.25 & 2.1 & 800 & 2400 \\
Glass wool & 0.16 & 0.041 & 840 & 12 \\
Plaster & 0.013 & 0.32 & 800 & 790 \\
\hline
\end{tabular}


Table 7. Summary of the meteorological data for the TIM-PCM wall experimentation

\begin{tabular}{cccccc}
\hline & $\begin{array}{c}\text { Mean daily } \\
\text { radiation on } \\
\text { vertical plan } \\
\left(\mathbf{W} . \mathbf{m}^{-2}\right)\end{array}$ & $\begin{array}{c}\text { Max radiation } \\
\text { on vertical } \\
\text { plan }\left(\mathbf{W} \cdot \mathbf{m}^{-2}\right)\end{array}$ & $\begin{array}{c}\text { Mean temp } \\
\left({ }^{\circ} \mathbf{C}\right)\end{array}$ & $\begin{array}{c}\text { Max temp } \\
\left({ }^{\circ} \mathbf{C}\right)\end{array}$ & $\begin{array}{c}\text { Min temp } \\
\left({ }^{\circ} \mathbf{C}\right)\end{array}$ \\
\hline December & 93.3 & 1000 & 9.5 & 20 & 1 \\
January & 62 & 905 & 8.3 & 20 & 2.7 \\
\hline February & 72.8 & 952 & 9.6 & 23.6 & 0.3 \\
March & 127.2 & 998 & 11.8 & 25.8 & 4.6 \\
\hline August & 116.3 & 568 & 26.7 & 40.9 & 18.9 \\
\hline
\end{tabular}

